\title{
THE IMPACT OF FISCAL POLICY ON ECONOMIC GROWTH IN NAMIBIA
}

Esau Kaakunga

Bank of Namibia

The purpose of this study was to shed light on the impact of fiscal policy on growth. Governments undertake expenditures to pursue a variety of goals, only one of which may be an increase in per capita income. Using the framework of endogenous growth models which seeks to explain sustained long term growth, we showed how a change in the mix of public spending in favour of productive activities could lead to a steady state growth rate. The explanatory variables, which affect growth positively, include capital expenditure, tax revenue and the terms of trade. The share of private consumption in GDP, fiscal deficit, the share of total public debt in GDP and current expenditure relate negatively to the growth rate of output.

JEL H30, H50

\section{1}

\section{Introduction}

Discussions on why governments grow have a long tradition, going back at least as far as Adolph Wagner (1890). More recently, the evolution of positive theories on governments, often under the banner of the "public choice school", has made the subject a rich area for intellectual and political debate (see Mueller, 1987). This view is based on the premise that public officials set economic policies in their own self-interest just as firms do. As Olson (1984) points out, the ideological debate over the relationship between increased government spending and economic performance provides little evidence to resolve the issue. There does not seem to be a strong relationship between government ideology and economic performance due, perhaps, to the absence of a clear relationship between ideology and the size of governments. Neither economic theory nor empirical evidence provides a clear-cut answer to the question on how fiscal policy affects economic growth. This study, however, follows the Musgrovian framework, which states that fiscal policy influences economic growth through its impact on allocative efficiency, the stability of the economy and the distribution of income. Musgrave (1976) has argued that although certain goods and services should be provided by the market, others should be provided by the government and be made available free of charge to the users. Conversely, efficient government sectors where relative factor productivities are high, will enhance aggregate output.

The Namibian Government has inherited an oversized public administration, as well as a budget that was too short on investment, excessively focused on a minority of the population, and is of questionable efficiency. The tax base is heavily dependent on diamond and uranium revenues, and is therefore sensitive to fluctuations in the prices of these two commodities. Current expenditure is still too high and capital expenditure too low. It is a challenge for the Government to change the composition of expenditures, increase efficiency, and contain their growth. The Namibian authorities face four important economic challenges: (i) reactivating growth, (ii) redirecting and restraining the growth of public expenditure, (iii) reducing poverty and (v) generating employment. Given the membership of Namibia in the common monetary area (CMA), fiscal policy remains the 
main tool of the Government to address the present extraordinary inequalities in income and access to social services. The objectives of this study are therefore, to examine the long-term effects of government spending and taxation on growth and to estimate the empirical relationship between budget deficit, total central government debt, private consumption and economic growth.

The remainder of the paper is outlined as follows: Section two deals with the economic growth, revenue and expenditure profile, followed by section three which surveys the literature. Section four considers the methodology applied, followed by the estimation and regression results. Section five presents the conclusions and policy guidelines.

\section{2}

\section{Economic growth, revenue and expenditure profile}

\subsection{Economic growth}

The GDP growth improved considerably after Independence, surpassing the 1.1 per cent average achieved during the pre-independence period (the period before 1990). The average growth rate for the post-independence period (1991-2004) was 4.4 per cent. The good performance experienced during the postindependence period can be attributed to the significant recovery of investment activity that raised the investment-GDP ratio to more than 20 per cent compared to 14.9 per cent recorded during the period 1985-1989. During the first half of the post-independence period (19911996) the economy grew at an annual average rate of 4.9 per cent. This growth rate was a result of the good performance of the mining and agriculture sectors during the same period. The growth rate nevertheless declined to an average of 3.1 per cent during the second half of the post-independence period (1997-2004). This was due to a contraction in mining and agricultural output. The reduction in the agricultural output can be attributed to the drought experienced during the same period, while the decline in the mining output was a result of the fall in commodity prices and the closure of the Tsumeb Corporation Limited (TCL) mines.

Table 1

Economic growth and government activities ${ }^{1}$

\begin{tabular}{|l|r|r|r|r|r|r|r|r|r|r|r|r|r|r|}
\hline & $\mathbf{1 9 9 1}$ & $\mathbf{1 9 9 2}$ & $\mathbf{1 9 9 3}$ & $\mathbf{1 9 9 4}$ & $\mathbf{1 9 9 5}$ & $\mathbf{1 9 9 6}$ & $\mathbf{1 9 9 7}$ & $\mathbf{1 9 9 8}$ & $\mathbf{1 9 9 9}$ & $\mathbf{2 0 0 0}$ & $\mathbf{2 0 0 1}$ & $\mathbf{2 0 0 2}$ & $\mathbf{2 0 0 3}$ & $\mathbf{2 0 0 4}$ \\
\hline GPP growth & 8.2 & 7.1 & -1.7 & 7.3 & 4.1 & 4.1 & 3.2 & 3.3 & 3.4 & 3.59 & 2.4 & 6.7 & 3.5 & 5.9 \\
\hline $\begin{array}{l}\text { Budget deficit as } \\
\text { percentage of } \\
\text { GDP }\end{array}$ & 2.4 & 4.9 & 3.4 & 1.6 & 3.6 & 5.8 & 2.5 & 3.9 & 3.2 & 1.4 & 3.6 & 3.0 & 6.0 & 4.5 \\
\hline $\begin{array}{l}\text { Expenditure as } \\
\begin{array}{l}\text { Percentage of } \\
\text { GDP }\end{array}\end{array}$ & 37.0 & 38.1 & 34.9 & 32.6 & 34.3 & 36.0 & 35.4 & 35.7 & 36.2 & 35.0 & 36.2 & 35.0 & 35.1 & 34.5 \\
\hline $\begin{array}{l}\text { Revenue as } \\
\text { percentage of } \\
\text { GDP }\end{array}$ & 28.8 & 27.7 & 28.1 & 26.5 & 27.2 & 26.6 & 29.5 & 28.3 & 30.0 & 30.6 & 32.1 & 31.6 & 29.0 & 29.8 \\
\hline
\end{tabular}

Source: Bank of Namibia.

\subsection{Revenue}

During the early to mid-1980s, revenues averaged about 26-28 per cent of GDP. Payments from the Republic of South Africa (RSA) in lieu of customs and excise duties (i.e. Southern African Customs Union [SACU] receipts) accounted for the bulk of the revenues of the Central Authority. Other sources (mainly company tax, special diamond taxes, and administrative fees and charges) contributed, on average, less than one-half of the total revenue. During the second half of the 1980s, revenues rose in relation to the GDP to 38.7 
per cent. The tax burden was relatively stable during the period 1990 to 2004, averaging 29.8 per cent of the GDP. The SACU receipts have continued to be a major source of revenue after independence. As a percentage of the total Government revenue, SACU receipts constituted about 37 per cent during the 2004/ 05 fiscal year compared with 25 per cent at independence in 1990. Similarly, as a percentage of GDP, SACU receipts increased from 8.11 per cent in 1990/91 to 11.6 per cent during 2000/01.

\subsection{Expenditure}

Public expenditure in Namibia includes all expenditures made by the Government, including those financed by fees and charges, as well as those from the general revenue fund and transfers to the state-owned enterprises. Since independence in 1990 there has been an increase in total expenditure. Over the period 1990-2004, total expenditure recorded an annual average growth rate of 15.5 per cent. As a ratio to the GDP, the total expenditure increased from 31.1 per cent in 1990/91 to 34.2 per cent in 2004/ 05 . The increase in the public expenditureGDP ratio was the result of the commitment by the Namibian Government to undertake extensive human capital formation by widening access to education and health for the majority of black Namibians who had been neglected by the former white minority regime of South Africa. Two other causes of this increase were the serious drought between 1992-1995 and the worldwide economic recession which affected the Namibian economy due to the trade openness of the country.

The current expenditure as a percentage of the total government expenditure increased from 83.8 per cent in 1990/91 to 86.7 in 1995/ 96 , before gradually rising to 84.5 per cent in 2004/05. Personnel expenditure, which consists mainly of salaries, remained a major component of the current expenditure. Personnel expenditure as a percentage of current government expenditure accounted for $53.6 \mathrm{per}$ cent and 51.2 per cent in 1990/91 and 2004/05 respectively. As a share of the GDP, current expenditure accounted for about 30 per cent for the period 1990/91-2004/05. During the first half of the post-independence period the current expenditure as a share of GDP recorded an average of 29.2 per cent, which increased slightly to 30.8 per cent in the second half of the post-independence period.

Interest payments increased sharply on average by 45.5 per cent between 1990/91 and 2004/05 annually. As a percentage of the GDP interest payments recorded 0.4 per cent and 2.8 per cent during 1990/91 and 2004/05 respectively. The significant growth in interest payments made it the fastest-growing component of current expenditure and also reflected the growth and the extent of total central government domestic debt in Namibia since independence. Capital expenditure, as a share of the total government expenditure, increased slightly from 15.3 per cent 1990/91to 15.5 per cent in 2004/05. As a share of the GDP, capital expenditure during the first half of the post-independence period recorded an annual average rate of 5 per cent. This share decreased slightly to 4.7 per cent during the second half of the post-independence period.

\subsection{Financing the deficit}

During the first half of the 1980s the government deficit averaged about 20 per cent of the GDP, most of it being financed by the support of the RSA (World Bank, 1991). Private sector borrowing (with a RSA guarantee) financed about 6 per cent of the GDP and, as a result, Namibia's public debt rose from less than 6 per cent of GDP in 1980/81 to an unprecedented 32.7 per cent of the GDP in 1983/84. During the second half of the decade a significant reduction in budget support from the RSA forced a sharp decline in the overall deficit to an average of 9 per cent of GDP, roughly equal to the volume of transfers received. This reduction in the deficit was achieved through an average increase in revenues equivalent to 8 per cent of the GDP and an average reduction in expenditures of about 3 per cent of the GDP (World Bank, 1994). Since independence, borrowing from the domestic market through the issuance of long- and short-term government paper had predominantly financed 
the deficit. The Government also drew down on cash balances at the Bank of Namibia and took up minor concessional loans from time to time.

\section{3}

\section{Literature review}

The role of government expenditure and taxation in economic growth has been regarded as an important issue in economics. Fiscal policy is a key to successful macroeconomic policy both because of its direct macroeconomic effects on the current allocation of resources and because all methods of financing a budget deficit have potential adverse macroeconomic consequences when used excessively. While it was clear, however, that distortionary taxation and government spending could affect the level of gross domestic product in a given country, the theoretical link between these factors and rate of growth has not been clearly established in the standard neo-classical model. Because the long-run growth in the early neo-classical models of Solow (1956) and Swan (1956) was due to an exogenous technical change, the fiscal stance had little effect on the rate of capital accumulation or the long-run rate of growth.

Contributions to the recent endogenous growth and government literature have, however, emphasised the role of the fiscal stance in influencing the rate of economic growth, with government spending directly affecting the private production function (see Easterly, 1989 and 1990; Barro, 1991; and Sala-i-Martin, 1992 and 1995). The effects of fiscal policy on aggregate demand and absorption, whether through reductions in government expenditures or increases in taxes, are widely debated. Public sector spending on currently produced goods and services is in itself a component of total domestic spending and this, of course, represents its direct contribution to absorption. If government purchases are limited to nontradable goods, they also represent an addition to aggregate demand for domestic goods. Public sector spending on traded goods will, however, only contribute to a worsening of the trade balance, while having no effect on real aggregate demand or on output and inflation (Cashin, 1995).

Private spending can also be reduced if increased public spending gives rise to an equal tax liability for the private sector, either in the present through tax financing or in the future due to the need to cease public debt. This is the well-known "Ricardian equivalence" proposition developed by Barro (1974). Finally, if nominal wages are flexible, or if the increase in public spending was foreseen at the time wage contracts were entered into, the domestic price level could rise sufficiently to reduce private spending by an amount equal to the increase in public spending, thereby leaving the total real aggregate demand unchanged. Barro (1990) includes productive government spending in a model of endogenous growth in which the growth is increasing for low levels of government expenditure and then decreasing when the size of the government sector increases beyond acceptable levels. The model also suggests that different types of government expenditure may have different impacts on growth.

Tax receipts from the private sector have no direct effect on absorption. They do, however, affect private disposable income and may thus have an indirect effect on private spending. The effect of a given tax on private spending is likely to depend on whether the tax is viewed as permanent or temporary (temporary taxes are expected to reduce saving). The characteristics of the recipient affect the marginal propensity to consume out of current income (including demographic factors such as age and household size), and relate to the nature of the financial system (which will affect the extent to which the taxpayers are liquidity constrained).

A study by OECD (2004) argued that distortionary taxes affect the economic choices of households and firms, notably with respect to the level and composition of their (human and physical) capital investment. By contrast, nondistortionary taxes are more neutral. Nondistortionary taxes mainly relate to taxation on domestic goods and services, while distortionary taxes include taxation on income and profits, as well as taxation on pay roll and manpower. 
Budget policy could have implications for growth in the sense that the level of public revenue relative to that of public expenditure, namely budget balance, may have growth effects that are separate to those related to the absolute level of either taxation or public expenditure (Tanzi \& Zee, 1997). If, for instance, the private sector regards budget deficits (even financed by debt) simply as taxes delayed, then it might choose to increase its own savings in order to neutralise the public dissavings, thus leading to an unchanged level of national savings. Alternatively, budget deficits might not induce a response in private sector savings, in which case, national savings would be reduced and growth would be hampered.

Various research works on fiscal policy and economic growth have yielded mixed results. For instance, Deverajan et al. (1993), Barro (1981) and Grier and Tullock (1989) classified current expenditure as productive and capital as unproductive, while researchers such as Landau (1983), Kormendi (1983), Aschauer (1987) and Romer (1986) classified current expenditure as non-productive and capital public spending as productive. It is argued that seemingly productive expenditures might be unproductive if there is an excessive amount of these. Some capital expenditures, such as the so-called white elephants and facilities that have been rendered useless by insufficient provision for running expenses, may not be productive. Several components of current expenditure, such as operations and maintenance, might have higher rates of return than capital expenditures (Deverajan et al., 1996). It is further argued that different forms of government spending might vary sharply in terms of productivity across countries, and cross-section analysis might thus yield mixed findings on the growth effects of fiscal policy.

A number of fiscal variables have been used in empirical studies to show the correlation between fiscal policy and economic growth. These variables include either government consumption or government spending, tax revenue and budget deficit.

\subsection{Government spending}

Most studies have emphasised the importance of distinguishing between productive and nonproductive spending. Barro (1989) used a crosssection of 98 countries, including industrial and developing countries, for the period 1960-1985. Regressors included the initial per capita GDP level, its squared value, the initial level of human capital, the ratio of government consumption to the GDP, and measures of political instability and market distortions. His results show that public consumption spending is systematically inversely related to growth and investment, while public investment tends to be positively correlated with growth and private investment. Barro (1991) finds a negative relationship between government consumption (excluding defence and education) and per capita GDP. Diamonds (1989) also finds overall government expenditure to be negatively related to growth, with some significant positive growth effects of directly productive current and capital expenditures for education but no strong effects for general infrastructural spending.

To detect a discernible growth effect, several of the studies focused on the components of government expenditure (Barro, 1989; Diamond, 1989; and Landau, 1983). Some of the studies supported a negative relationship between the ratio of government consumption to the GDP and the rate of growth of the output. On the other hand, the average ratio of infrastructure expenditure to the GDP has been found to exert a positive impact on long-run growth in other studies (Barro 1989, Diamond 1989, and Orsmond 1990). The positive impact on the growth of the average ratio of expenditures on education and health has also been generally confirmed. Kormendi and Meguire (1985), however, reported that the average growth rate of the ratio of government consumption to the GDP is not closely associated with growth. De Gregorio (1992) and Ojo and Oshikoya (1995) have found that government consumption is negatively related to growth. The general finding is, however, that there is a negative correlation between growth and government consumption. In their crosssectional analysis Deverajan et al. (1996) have 
found that the standard candidates for productive expenditures such as capital, transport and communication, health and education, had either a negative or an insignificant relationship with economic growth. The only broad category that was associated with higher economic growth was current expenditure.

\subsection{Tax policy}

Attempts to capture the effects of taxes on growth have also produced mixed results. In trying to obtain an aggregate measure of the potentially negative implications of government activity, many researchers use government consumption spending as a proxy for the distortionary taxes that must be raised to support that spending. Given the difficulty in obtaining data, efforts have been made to also test for the impact of taxes on growth. Koester and Kormendi (1989) for instance, try to examine the differential effects of marginal and average taxes. They use the tax-GDP ratio as a measure of average taxes and interpret the regression coefficient of the GDP on taxes as a marginal tax rate. They find that taxes do not have growth effects.

Skinner (1987) and Manas-Anton (1987) analyse the differential effects of direct versus indirect taxation. Skinner (1987) finds evidence that individual and corporate taxes have greater negative growth effects than trade or sales taxes in Africa, but Manas-Anton (1987) finds little support for a greater negative impact of direct versus indirect taxes. Orsmond (1990) disaggregated tax effects and concluded that the ratio of import taxes to the GDP was positively associated with the growth rate of output. Easterly and Rebelo (1994) experimented with thirteen different tax measures and found only one marginal income tax rate computed by a time-series regression of income tax revenue on the GDP to be statistically significant in explaining growth variations among their sample countries. Engen and Skinner (1992) found a statistically significant relationship between growth and the rate of change in tax levels.
The empirical analysis of OECD 2004 found that taxes and government expenditures seem to affect growth both directly and indirectly through investment. An increase of about one percentage point in the overall tax level, i.e. slightly less than has been observed over the past two decades in the OECD sample, could be associated with a direct reduction of about 0.3 per cent in output per capita. If the investment effect is taken into account, the overall reduction would be about 0.6-0.7 per cent.

\subsection{Budget policy}

In their study, Easterly and Rebelo (1991) found a negative and significant correlation between budget deficit and growth. Martin and Fardmanesh (1990) found the correlation significant and negative only for middle-income countries. Levine and Renelt (1992) found the correlation fragile. In his study on the size and composition of the public sector and the economy, Orsmond (1990) found that a budget deficit as a share of the GDP was negatively and statistically correlated with economic growth.

\section{4}

Methodology

The endogenous growth theories hold the potential for explaining aspects of growth that the standard neo-classical growth models are not equipped to deal with. For instance, in most developing nations where stabilisation measures have been implemented, considerable levels of under-utilisation of capacity exist (for example in Ghana the rate of capacity utilisation at the beginning of economic recovery programme (ERP) was 30 per cent). In such circumstances an appropriate macro-economic policy mix could lead to growth (Jebuni et al., 1991). The endogenous growth theory has therefore demonstrated that macroeconomic policies that affect savings and investment rates show an increase in both the short-run and the steady state growth rates.

Time series properties of data are often not very satisfactory. In most cases the data series are not stationary. Most of the classical 
assumptions for econometric estimation and forecasting are thus violated. In the present study the Augmented Dickey-Fuller (ADF) test is therefore used to test for the stationarity of the data. Both the constant and the trend were included in the testing of the stationarity. The $\mathrm{ADF}$ test shows that all the variables, except for the share of total central government debt in the GDP, are non-stationary. Having confirmed that most data series are non-stationary in levels, further tests were conducted to establish whether the data series were stationary in first difference or not. The results show that the variables were stationary in first difference when constant and trend are included. Each of the original variables was therefore integrated in the first order. A test for co-integration using the Augmented Dickey-Fuller test furthermore revealed that the dependent variable was cointegrated with the independent variables.

Table 2

Unit root tests

\begin{tabular}{|l|l|l|}
\hline & ADF & I(d) \\
\hline$\triangle$ CAPTGE & -6.1147 & $\mathrm{I}(1)$ \\
\hline$\Delta$ CURTGE & -6.2588 & $\mathrm{I}(1)$ \\
\hline$\Delta$ DEFGDP & -6.4258 & $\mathrm{I}(1)$ \\
\hline$\Delta$ GRGDP & -6.1541 & $\mathrm{I}(1)$ \\
\hline$\Delta$ OPEN & -3.5157 & $\mathrm{I}(1)$ \\
\hline$\Delta$ TRGDP & -4.0432 & $\mathrm{I}(1)$ \\
\hline TCDGDP & -3.5577 & $\mathrm{I}(0)$ \\
\hline$\Delta$ PC & -5.1108 & $\mathrm{I}(1)$ \\
\hline
\end{tabular}

Source: Regression results. I(d) refers to the order of integration.

Table 3

Co-integration test using ADF

\subsection{Model specification}

For the empirical testing we follow the econometric specification of the Cashin 1995 endogenous growth model, and thus consider the following specifications.

$\Delta$ GRGDP $_{\mathrm{t}}=\beta_{0}+\beta_{1} \Delta \log \mathrm{OPEN}_{\mathrm{t}}+\beta_{2} \Delta \log \mathrm{PC}_{\mathrm{t}}$ $+\Delta \beta_{3}$ DEFGDP $_{\mathrm{t}}+\beta_{4} \Delta \log$ TPDGDP $_{\mathrm{t}}+$ $\beta_{5} \Delta \log$ CAPTGE $_{\mathrm{t}-2} \beta_{6} \Delta \log \mathrm{TRGDP}_{\mathrm{t}}+\mathrm{U}_{\mathrm{t} 1}$

$\Delta$ GRGDP $_{\mathrm{t}}=\mathrm{a}_{0}+\alpha_{1} \Delta \log \mathrm{OPEN}_{\mathrm{t}}+\alpha_{2} \Delta \log \mathrm{PC}_{\mathrm{t}}+$ $\alpha_{3} \Delta$ EFGDP $_{t}+\alpha_{4} \Delta \log$ PPDGDP $_{t}+\alpha_{5} \Delta \log$ CURTGE $_{\mathrm{t}-2}+\alpha_{6} \Delta \log \operatorname{TRGDP}_{\mathrm{t}}+\mathrm{U}_{2 \mathrm{t}}$

Where GRGDP is real GDP growth rate, CURTGE is the share of the current expenditure in the total government expenditure, CAPTGE is the ratio of capital expenditure to the total government expenditure, TRGDP is the share of total tax revenue in GDP, DEFGDP is the ratio of the fiscal deficit to the GDP, OPEN is the share of the sum of exports and imports in the GDP, PC is the share of private consumption in the GDP, TCDGDP is the share of the total Central Government in the GDP and U is the random error term assumed to be Gaussian white noise. All variables (except GRGDP and DEFGDP) are entered in logarithmic form. The inclusion of variables in the various equations was based on the performance of each variable. The equations were estimated using the ordinary least squares (OLS) regression method and the EVIEWS 4.1, an econometric software package, was used to analyse the annual data for the period 1980-2002. The fiscal year data were converted into the calendar year. The lag was 
introduced into the equations by allowing the system to drop the insignificant variables, but most of the variables did not perform well. Only capital and current expenditures lagged by 2 years have given results that seem to be robust.

\subsection{Sources and nature of data}

The primary source for data on public expenditure, budget deficit, total public debt and revenue was the Estimates of Expenditure and Revenue published by the Ministry of Finance. The data on private consumption, gross domestic product and imports and exports were obtained from the National Accounts published by the Central Bureau of Statistics.

\subsection{The empirical results}

The signs of all the coefficients of the explanatory variables were as expected. The results showed that the coefficient of the share of the sum of exports and imports in the GDP promote economic growth. The coefficient was statistically significant in all the equations at 10 per cent level. The results supported the proposition that openness affects growth positively. The results also showed that the share of private consumption in the GDP was at 5 per cent and 10 per cent levels negatively and significantly related to economic growth in equations 1 and 2 respectively. The sign of the coefficient of the variable conformed with the traditional theory that consumption does not lead to economic growth. An increase in consumption implies a reduction in savings only for a given level of national income, which will slow the growth rate of investment and thus lower the rate of economic growth.

\section{Table 4}

Regression results: Growth equations with growth rate of the real GDP $(\triangle G R G D P)$ as a dependent variable

\begin{tabular}{|c|c|c|}
\hline \multicolumn{3}{|c|}{ Equation number } \\
\hline $\begin{array}{l}\text { Explanatory } \\
\text { Variable }\end{array}$ & $\begin{array}{l}(1)^{*} \\
\text { OLS }\end{array}$ & $\begin{array}{l}(2) \\
\text { OLS }\end{array}$ \\
\hline Constant & $\begin{array}{c}0.3057 \\
(0.7219)\end{array}$ & $\begin{array}{c}0.2823 \\
(0.6734)\end{array}$ \\
\hline$\triangle \operatorname{logOPEN}$ & $\begin{array}{c}9.9490^{*} \\
(1.5666)\end{array}$ & $\begin{array}{c}10.2772 * \\
(1.6163)\end{array}$ \\
\hline$\Delta \log P C$ & $\begin{array}{c}-9.8428^{*} \\
(-1.9025)\end{array}$ & $\begin{array}{c}-9.1792^{*} \\
(-1.5587)\end{array}$ \\
\hline$\triangle$ DEFGDP & $\begin{array}{l}-0.2752^{* *} \\
(-2.2462)\end{array}$ & $\begin{array}{l}-0.2801^{* *} \\
(-2.2244)\end{array}$ \\
\hline$\Delta \log T C D G D P$ & $\begin{array}{l}-3.7820^{* * *} \\
(-2.9147)\end{array}$ & $\begin{array}{l}-3.5835^{* * *}+ \\
(-2.7440)\end{array}$ \\
\hline$\Delta \operatorname{logCURTGE}{ }_{\mathrm{t}}$ & $\begin{array}{l}- \\
-\end{array}$ & $\begin{array}{l}-1.5688 \\
(-0.1006)\end{array}$ \\
\hline$\Delta \log C$ APTGE $_{\mathrm{t}-2}$ & $\begin{array}{c}1.3091 \\
(.0 .4168)\end{array}$ & $\begin{array}{l}- \\
-\end{array}$ \\
\hline$\Delta \log T R G D P$ & $\begin{array}{c}15.5936^{* *} \\
(2.4972)\end{array}$ & $\begin{array}{c}14.8213^{* *} \\
(2.3756)\end{array}$ \\
\hline $\operatorname{ECM}(-1)$ & $\begin{array}{l}-1.4672^{* * *} \\
(-7.2480)\end{array}$ & $\begin{array}{l}-1.4691^{* * *} \\
(-7.0523)\end{array}$ \\
\hline $\begin{array}{l}\text { Adjusted R } \\
\text { F } \\
\text { DW }\end{array}$ & $\begin{array}{r}.7961 \\
11.5943 \\
1.6157\end{array}$ & $\begin{array}{r}.7933 \\
11.4154 \\
1.6711\end{array}$ \\
\hline
\end{tabular}

Source: Regression results. T-ratios are in parentheses; ${ }^{* * *} 1$ per cent significance level; ** 5 per cent significant level; * 10 per cent significant level. 
The empirical results show that the share of capital expenditure in total government expenditure relates positively to economic growth. The coefficient is statistically insignificant. These findings support the traditional theory that public capital spending on capital goods adds to the physical capital of the country. It is recognised that the public construction of rails, ports, bridges, dams and power stations facilitate private sector production. These insignificant results may result from the fact that capital expenditure as a share of the GDP for the Namibian economy is small. This fact is reinforced by the rather slow response of the private sector in Namibia to the improvements in the basic economic infrastructure.

The results have indicated a negative relationship between the share of the current expenditure in total government expenditure and economic growth. The sign of the coefficient of the variable conformed to the traditional view that current expenditure does not lead to economic growth. This is due to current expenditure being a consumption item and hence non-productive. This can be explained by the fact that government current expenditure, financed by either higher tax rates or higher inflation through the deficit finance, introduces distortions which reduce saving and do not boost growth in public investment either directly or private productivity indirectly. Recent studies on current expenditure and economic growth have, however, emphasised the need to look at the various components of current expenditure, because it is argued that current expenditure in the growth oriented expenditures such education and health may have a higher return than capital expenditure (Deverajan et al., 1996). Thus, the empirical results on the relationship between economic growth and current expenditure in the developing economy would not be conclusive.

The share of tax revenue in the GDP was found to have a positive growth effect. It is interesting to note that the coefficient of the share of tax revenue in the GDP was statistically highly significant at a 5 per cent level in both equations. The study did not disaggregate tax effects on long-term growth due to data problems. Recent data indicated that more than 50 per cent of budgetary allocations come from tax revenue, especially the revenue from SACU. The highly significant positive impact of tax revenue on output growth might be attributable to these sources of revenue. The empirical results also indicated a negative relationship between the share of the budget deficit in the GDP and economic growth. This was statistically significant at 5 per cent level in both equations. The results show that budget deficits were not good for growth. The coefficients of the share of the total central government in the GDP maintained the sign. The coefficient was highly statistically significant at 1 per cent in all the equations. The diversion of portions of domestic output from growth-producing savings towards debt servicing would not enhance economic growth.

\section{5}

\section{Conclusions}

The study attempted to survey the conceptual and empirical relationship between fiscal policies and the long-term growth of the Namibian economy. Using a simple, analytical endogenous growth model, the effects of government spending and taxation on growth were identified. The model also established an empirical relationship between the budget deficit, total central government debt and private consumption and economic growth. The main findings of the econometric estimation could be summarised as follows. The results provided support for those who advocate that capital expenditure, the sum of exports and imports of goods and services (openness) and the effective mobilisation of government tax revenue promote economic growth. The statistical significance and expected signs, budget deficits, current expenditure, private consumption and total central government debt are negatively related to growth.

The fiscal policy options for implications were straightforward. Tightened control over government current expenditure with the view to reducing waste in the public sector was needed. In public investment programming, 
adequate appraisal methods were to be used to secure a consistent and optimal ranking of projects.

Ceteris paribus, the implementation of these policy guidelines would assist in reducing the fiscal deficits and the total central government debt. The resulting stable macroeconomic environment from a low fiscal deficit and government debt would enhance prospects for a higher rate of private investment and thus ensure a smoothing expansion in output in the years ahead and in smoothing the path of a longterm economic development.

\section{Endnotes}

1 The data of the fiscal variables in Table 1 is converted into the calendar year. It might not correspond with the subsequent discussions. The data in the calendar were used for the regression analysis.

\section{References}

1 AlESinA, A. \& PEROTTI, R. (1997) "Fiscal adjustment in OECD countries: composition and macroeconomic effects", IMF Staff Papers, 44(2): 210-48.

2 ASCHAUER, D.A. (1987) "Is public expenditure productive?", Journal of Monetary Economics, 23(2): 177-200.

3 BARBA, A. (2001) "Rethinking expansionary fiscal retrenchments", Contributions to Political Economy, 20(1): 57-86.

4 BARRO, R.J. (1974) "Are government bonds net wealth", Journal of Political Economy, 82(6): 1095-1117.

5 BARRO, R.J. (1981) "Output effects of government purchases", Journal of Political Economy, 89(6): 1086-1121.

6 BARRO, R.J. (1989) "A cross-country study of growth, saving and government", NBER Working Paper, no. 2855, National Bureau of Economic Research: Cambridge, Massachussetts.

7 BARRO, R.J. (1991) "Economic growth in a cross-section of countries", Quarterly Journal of Economics, 106(2): 407-444.

8 BARRO, R.J. \& SALA-I-MARTIN, X. (1992) "Public finance in models of economic growth", Review of Economic Studies, 59(4): 654-661.

9 BARRO, R.J. \& SALA-I-MARTIN, X. (1995) Economic Growth, McGraw-Hill: New York.
"Government spending, taxes and economic growth”, IMF Staff Papers, 42(2): 237-269.

10 CASS, D. (1965) "Optimal growth in an aggregative model of capital accumulation", Review of Economic Studies, 32(July): 233-240.

11 DE GREGORIO, J. (1992) "Economic growth in Latin America", Journal of Development Economics, 39(1): 58-84.

12 DEVARAJAN; J., SWAROOP, V. \& ZOU, H. (1996) "The composition of public expenditure and economic growth", Journal of Monetary Economics, 37(2-3): 331-44.

13 DIAMOND, J. (1989) "Government expenditure and economic growth: an empirical investigation", IMF Working Paper, no. 89/45: Washington D.C.

14 DOMAR, E.D. (1946) "Capital expansion, rate of growth and employment", Econometrica, April.

15 EASTERLY, W. (1989) "Policy distortions, size of government and growth", NBER Working Paper, 3214, National Bureau of Economic Research: Cambridge, Massachusetts.

16 EASTERLY, W. (1990) "Endogenous growth in developing countries with government induced distortions", unpublished, Macroeconomic Adjustment and Growth Division, World Bank: Washington.

17 EASTERLY, W. \& REBELO, S. (1994) "Fiscal policy and economic growth: An empirical investigation", Discussion Paper, Centre for Economic Policy Research.

18 ENGEN, E.M. \& SKINNER, J. (1992) "Fiscal policy and economic growth", NBER Working Paper, 4223, National Bureau of Economic Research: Cambridge, Massachussetts.

19 GRIER, K.B. \& TULLOCK, G. (1989) "An empirical analysis of cross national economic growth", Journal of Monetary Economics, 24(2): 259-276.

20 HARROD, R.F. (1939) "An essay in dynamic theory", The Economic Journal, March.

21 HIRSCHMAN, A. (1958) The Strategy of Economic Development, New Heaven.

22 JEBUNI, C.D.; SOWA, N.K. \& TUTU, K.A. (1991) "Exchange rate policy and macroeconomic performance in Ghana”, $A E R C$ Research Paper, 6.

23 KAAKUNGA, E. (1997) "The composition of government expenditure and economic growth: The case study of Namibia”, M.Phil Thesis, University of Ghana: Legon.

24 KHAN, A.G. (1992) "Policies for long-run economic growth: A summary of the bank's 1992 symposium”, Economic Review. 
25 KHAN, S.M. \& VILLANUEVA, D. (1991)

"Macroeconomic policies and long-term growth", AERC Special Paper, 13.

26 KNIGHT, M.; LOAYZA, N. \& VILLANUEVA, D. (1993) "Testing the neoclassical theory of economic growth: A panel data approach", IMF Staff Paper, 40: 512-541.

27 KOESTER, R.B. \& KORMENDI, R.C. (1987) "Taxation, aggregate activity and economic growth: cross-country evidence on some supplyside hypotheses", Economic Inquiry, 27(3): 7793.

28 KORMENDI, R.C. (1983) “Government debt, government spending and private behaviour", American Economic Review, 73(5): 994-1010.

29 KORMENDI, R.C. \& MEGUIRE, P.G. (1985) "Macroeconomic determinants of growth: Crosscountry evidence", Journal of Monetary Economics, 16(2): 141-163.

30 LANDAU, D. (1983) "Government expenditure and economic growth: a cross-country study", Southern Economic Journal, 49(3): 783-792.

31 LEVINE, R. \& RENELT, D. (1992) "A crosscountry studies of growth and policy: methodological conceptual, and statistical problems", World Bank, Working Papers, 608.

32 MANAS-ANTON, L.A. (1987) "Relationship between income tax ratios and growth rates in developing countries: A cross-country analysis", In V Ghandi (ed.) Supply-Side Tax Policy, IMF: Washington, D.C.

33 MARTIN, R. \& FARDMANESH, M. (1990) "Fiscal variables and growth: A cross-section analysis", Public Choice, 64: 239-251.

34 MCDERMOTT, C.J. \& WESCOTT, R.F. (1996) "An empirical analysis of fiscal adjustments", IMF Staff Papers, 43(4): 725-753.

35 MUELLER, D.C. (1987) "The growth of government: a public choice perspective", IMF Staff Papers, 34(1): 115-149.

36 MUSGRAVE, R.A. (1976) Public Finance in Theory and Practice ( $2^{\text {nd }}$ ed.) McGraw-Hill.

37 ORGANISATION FOR ECONOMIC COOPERATION AND DEVELOPMENT (2004) Understanding Economic Growth: A Macro Level, Industry Level and Firm Level Paris.
38 OJO, O. \& OSHIKOYA, T. (1995) "The determinants of long-term growth: Some African results", Journal of African Economics, 24(2): 166-191.

39 OLSON, M. (1984) "Beyond Keynesian and monetarism", Economic Inquiry, 22(3): 297-322.

40 ORSMOND, D.W.H. (1990) “The size and composition of the public sector and economic growth: a theoretical and empirical review", IMF, Unpublished: Washington.

41 RAM, R. (1986) "Government size and economic growth: A new framework and some evidence from cross-section and time-series data", American Economic Review, 76(1): 191203.

42 RAMSEY, F. (1928) "A mathematical theory of saving”, Economic Journal, 38(December): 543559.

43 REBELO, S. (1991) "Long-run policy analysis and long-run growth", Journal of Monetary Economics, 99(June): 1002-1037.

44 ROMER, P.M. (1986) "Increasing returns and long-run growth", Journal of Political Economy, 94(5): 1002-1037.

45 SKINNER, J. (1987) "Taxation and output growth: Evidence from African countries", NBER Working Paper, 2335, National Bureau of Economic Research.

46 SOLOW, R. (1956) "A contribution of the theories of economic growth", Quarterly Journal of Economics, 70(February): 65-94.

47 SWAN, T. (1956) "Economic growth and capital accumulation", Economic Record, 32: 334-361.

48 TANZI, V. \& ZEE, H. (1997) "Fiscal policy and long-run growth", IMF Staff Papers, 44(2): 179209.

49 VILLANUEVA, D. (1994) "Openness, human development, and fiscal policies: Effects on economic growth and speed of adjustment", IMF Staff Papers, 541(1): 1-29.

50 WAGNER, A. (1890) Finanzwissenchaft, Part 2, Leipzig.

51 WORLD BANK (1991) Namibia: Poverty Alleviation with Sustainable Growth, Washington, D.C.

52 WORLD BANK (1994) Public Expenditure Review in Namibia, Washington, D.C. 